\title{
Factors affecting the marketing of perishables agricultural produce in Minna metropolis, Niger State, Nigeria
}

\author{
Onuk, E. G. ${ }^{1^{*}}$, Shehu, N. D. ${ }^{2}$ and Anzaku, T. A. K. ${ }^{2}$ \\ ${ }^{1}$ Nasarawa State University, Keffi Shabu-Lafia Campus, Nassarawa State, Nigeria. \\ ${ }^{2}$ College of Agriculture, Lafia, Nassarawa State, Nigeria. \\ *Corresponding author. Email: galadima1954@gmail.com
}

\begin{abstract}
Copyright (@) 2018 Onuk et al. This article remains permanently open access under the terms of the Creative Commons Attribution License 4.0, which
\end{abstract} permits unrestricted use, distribution, and reproduction in any medium, provided the original work is properly cited.

Received 10th May, 2018; Accepted 8th June, 2018

\begin{abstract}
The study examined some of the factors affecting the marketing of perishable agricultural crops in Minna. A simple random sampling was used to select 100 respondents from three major markets. Data were obtained through interview with the use of a structured questionnaire and analyzed using descriptive statistics. The results revealed that $70 \%$ of the marketers were within the ages of 31 to $50 y e a r s$ and the marketing of these perishable crops is dominated by the female gender (69\%). Analysis also show that $71 \%$ of the marketers had no contact with extension officers and consequently $73 \%$ had no access to credit facilities in the study area. Furthermore, majority of the marketers (61\%) had marketing experience of between 6 to 15years. The marketers recorded most losses (58\%) during transportation and $60 \%$ during loading and offloading. Using Tobit regression model, it was discovered that the $t$-value shows among other variables that four (4) were significant: education $\left(X_{3}\right)$, credit $\left(X_{8}\right)$, and cooperative $\left(X_{9}\right)$ positively influences marketing, indicating that a unit increase in any of the variables will have a positive impact in agricultural production. While transportation cost $\left(X_{6}\right)$ had a negative coefficient implying that the amount spent on transporting these crops creates a marketing margin. The sigma t-value $=14.142$, implies that the overall model used is significant at $1 \%$. The study concludes that small holder farmers are responsible for producing the nation's food, but are faced by various constraints in marketing of these produce, hence it is recommended that farm household should be encouraged to have access to education, favorable credit condition, increased investment in rural and market infrastructure by the government and sensitization of the importance of cooperative membership by NGO's among others.
\end{abstract}

Key words: Agriculture, food loss, inputs, marketing, vegetable.

\section{INTRODUCTION}

Agriculture is important to the society in terms of poverty alleviation, food security and economic growth. It is the backbone of many African economies (Balarane and Oladele, 2012). Many people depend on agriculture for their livelihoods, an estimated 86 percent of rural people rely on agriculture as a livelihood option and it provides jobs for 1.3 billion smallholders and landless workers (Tita, 2008/9). Since the mid-eighties, the Government of India identified horticulture (vegetable) crops as a means of diversification for making agriculture more profitable through efficient land use, optimum utilization of natural resources and creating skilled employment for rural masses (Samantaray et al.,2009).

The sharp division between small scale and commercial farming further explains why unequal distribution of agricultural inputs such as land, farm assets, support services, market access, infrastructure and income persists in Nigeria. The subsistence sector involves smallscale production which is highly labour intensive with low farm capital investment and little division of labour (Antwi and Seahlodi, 2011). Also, majority of small-scale farmers lack access to adequate marketing facilities, which when exist are grossly underdeveloped and inefficient (Salami et al., 2010). Among commercial farmers, however, there is 
high capital investment, high level of divisions of labour and patronage of both local and international markets. Agricultural development will not occur without engaging small scale farmers who account for the overwhelming majority of actors in this sector and engaging in profitable agriculture means, generating maximum returns from the resources expended and formal markets (Barham and Chitemi, 2009).

Production of tomatoes, pepper and vegetables has its own complexity. There perishability and hugeness makes them difficult to manage easily during postharvest period unlike that of dry grains. Because of such perishable nature of the produce and lack of knowledge as well as shortage of capital, horticulture industry in sub-Saharan Africa in general and Nigeria in particular still at its infant stage. The other reason is that most of these perishables are produced by small-scale farmers those who have limited knowledge and financially poor in this region.

But small-scale vegetable farms are based on low input - low output production systems (Olayemi et al., 2012). The use of improved seeds and agro-chemicals is not common in the small-scale sector. Technical training and extension services on improved crop husbandry techniques are not available. As a result, average productivity of the crops is low both in quality and quantity. Losses of agricultural products also occur at all stages in the postharvest chain in the small-scale farming sector of developing countries. Therefore, postharvest loss is very common both during pre- and post-harvest periods which have a negative impact on the food security program of the countries in the region. Gustavsson et al. (2011) stated that food loss and waste reduction is equally important to that of intensive and extensive farming to secure food for a nation. Losses cause less food to be available and therefore contribute to food insecurity. Producing food that will not be consumed also leads to unnecessary $\mathrm{CO}_{2}$ emissions in addition to loss of economic value of the food produced. FAO (2012) roughly estimated that yearly global quantitative food losses and waste reached at 40 to $50 \%$ for fruits, vegetables and root crops. Olayemi et al. (2012) also estimated that as much as $25 \%$ and $40 \%$ fruits and vegetables, respectively, are lost after harvest and concluded that farmers experienced serious postharvest losses particularly due to poor postharvest handling measures in their study in Nigeria.

Marketing is a business activity associated with the flow of goods and services from producers to consumers. Marketing of agricultural products begins on the farm with planning of production to meet specific demand and market prospects (Bothloko and Oladele, 2013). Marketing information and market prices guide the farmer in making informed decisions, and also assist farmers for planning at pre-planting stage and to sell the surpluses that have been produced. In the absence of marketing information, the retail end of the industry does not respond to supply and demand and the pricing is artificially static or unchanged (Xaba and Masuku, 2012). Marketing plays a critical role in meeting the overall goals of economic development, food security, poverty alleviation and sustainable agriculture, especially among smallholder farmers in developing countries (Bothloko and Oladele, 2013). Marketing occupies a significant position in an exchange economy, especially in areas where increasing commercial activities and high rate of urbanization exist (Nwaneri et al., 2016). Onyenobi, et al. (2015) reported that the factors that determine the participation by male and female heads of households in agricultural marketing include socio-economic characteristics (age, marital status, educational level, household size, dependency ratio, membership of cooperative society, road conditions between markets, access to products traded, access to market information, and specific marketing factors (quantity of product traded, price of product, marketing cost and income from trade) that influence the supply of agricultural from the farmer to the final consumer.

Deficiencies in rural infrastructural services result in poor functioning domestic markets with little spatial and temporal integration, low price transmission and weak international competitiveness. Marketing constraints or challenges arise due to many factors such as limited knowledge and use of market information, lack of access to high-value reliable markets, high transactional costs, distance from the markets, poor quality of products, lack of storage facilities, low educational levels of small-scale farmers, poor agricultural extension services, lack of financial support, inadequate and inaccessible market infrastructure, lack of adequate access to finance, socioeconomic factors of the farmer (training, farming experience, age, level of education and household size) lack of access to decent roads, price risk and uncertainty, electricity, poor communication, information regarding prices, inadequate local markets, lack of bargaining power, excess of intermediaries (Xaba and Masuku, 2012, Antwi and Seahlodi, 2011).

These marketing constraints constitute the greatest barrier for small-scale farmers when it comes to access high value markets, and these factors restrain farmers from making decisions to participate in the market. Access to markets is an essential requirement for the poor in rural areas. It may also be easy to access markets, but retaining one's position in the market is more difficult and participation of small-scale farmers in high-value markets is unsatisfactory (Baloyi, 2010), and the perishable nature of vegetables necessitate effective marketing channels. Therefore, overcoming marketing constraints is critical for small-scale farmers to access lucrative markets. Shifting the focus from production-oriented programmes to more market-oriented interventions will place a renew attention on institutions of collective action, such as farmer groups, as an efficient mechanism for enhancing market performance (Barham and Chitemi, 2009).

Agriculture and marketing are two words that go together. This is because the source of food and other economic products must be reasonably accessible in 
distributing agricultural products to the markets and factories. Therefore, adequate marketing network and efficient distribution channels are necessary conditions affecting an efficient physical distribution of perishable crops in major part of the country. The marketing of perishable agricultural produce warrants special attention for several reasons. First, the marketers aim is to be able to bring his product directly or indirectly from the production centre into the hands of the final consumers at an affordable price and a reasonable level of profit, it suffices to say here that the marketers find it difficult to fully actualise this purpose because they are constrained by the nature of these produce and other marketing constraints in carrying out their marketing function. If agriculture is to respond to the growing demand of consumers, then it will be necessary to increase the production centers of these crops as well as to evolve a good progressive rural roads linking to major markets. Since most of the perishable crops are cultivated in rural areas, the need to link the markets and these rural areas is enormous hence it becomes a major problem in the marketing and distribution of these perishable crops in Niger state and Nigeria as a whole.

\section{Justification of the Study}

Marketing of Agricultural outputs is important in Nigeria economy. This is because after production, every farmer is faced with the problem of selling the farm produce. Once the market has been found, the farmer sets into machinery what will enhance the movement of the farm outputs to the ultimate consumers. Therefore, the importance of this study is to examine the gainful and developmental contributions agriculture can make to the economy and most importantly to the tremendous influence of marketing infrastructure in Niger State, Nigeria and the world at large. This necessitates the need for the study of marketing perishable vegetables so as to make appropriate recommendation of the efficient marketing of the vegetables in order to improve the people's food security status, and enhance the marketing employment of the crop. Ikujebi (2017) also reported that adequate marketing network and efficient distributing channels are necessary conditions and efficient physical distribution of perishable crops in major parts of the country.

The research will also assist in identifying some of the problems leading to post-harvest food losses and recommend appropriate measures to tackle them. This in turn will help ensure food security which goes beyond food production to include distribution and marketing. In developing countries such as Nigeria, marketing of crops is faced with problems which increase seasonal price variations. This has negative influence on the efficiency of the marketing system of most agricultural commodities such as vegetables. Umeh et al. (2016) reported that despite all the marketing problems of the vegetables which affect its demand and price, the demand for vegetables continue to be high.

\section{Objective of the study}

The main objective of this study is to examine the socio economic factors affecting the marketing of perishable agricultural products in Minna metropolis. The specific objectives are:

i. to determine the socio-economic characteristics of the respondents.

ii. to determine some of the factors influencing the marketing of perishable produce.

iii. to determine the factors responsible for the losses of perishable produce.

iv. to investigate the constraints associated with the marketing of perishable produce.

\section{RESEARCH METHODOLOGY}

\section{The study area}

Minna is the state capital of Niger state, and it lies between the latitude of $3.20^{\circ}$ East and longitude 8 and $11.3^{\circ}$ North. It is bordered to the north by Sokoto state, west by Kebbi state, south by Kogi state and south-west by Kwara. Kaduna and federal capital territory border the state to both North-east and South-east respectively. The state has a common boundary with the Republic of Benin along New Bussa, Agwara and Wushishi local government area, giving rise to common inter border trade between the two countries. Minna has a geographical base of undifferentiated basement complex rock of mainly quartz and manganite situated at the base of prominent hills in an undulating plain. The areas are underlain by clay and loamy soil which are good for farming (NIGIS, 2014).

The study area is located in a savannah belt which is characterized by two major types of seasons in a year; the wet and dry season. The annual rainfall received within the region is about $1,334 \mathrm{~mm}$ (52 inches) and the highest mean monthly rainfall is received in the month of September with almost (117 inches). The raining season starts in April and last between one hundred and ninety to two hundred (190-200) days. The mean monthly temperature is highest in March at $30.5^{\circ} \mathrm{C}\left(87^{\circ} \mathrm{F}\right)$ and the lowest in August at $25.1^{\circ} \mathrm{C}\left(77^{\circ} \mathrm{F}\right)$ (NIMET Minna, 2014). The vegetation of Minna is the tropical savannah type, which changes in nature with the seasons annually. During the wet season the vegetation is evergreen while in the dry season it dries up with trees losing their leaves and the grasses dry up. The vegetation tends to be thick and greenish no matter the season along the river course, because along the river course the soil is frequently wet and this result to the occurrence of dark green vegetation within the area. 


\section{Sampling technique}

The population of the study includes the marketers of tomatoes, pepper and vegetables in the three major selected markets. Kure ultra-Modern market, Tungan goro market and Tunga market. A research questionnaire was administered and distributed to a random sample of 100 respondents in 3 major different markets in Minna. The selection was based on the population of vegetable marketers in each case. The questionnaires were divided into three (3) sections, A, B and C. While section A addresses the socio economic background of the respondents, section $B$ addresses cultivation pattern, price and distribution of perishable crops, section $\mathrm{C}$ addresses methods of storage, losses as well as other problems and the opinion of the marketers as regards better ways of marketing perishable agricultural produce.

\section{Data analysis}

The combination of analytical techniques was used to analyze the data. These include descriptive statistics (frequencies, percentage \& means) to determine the constraints/factors among marketers and small scale farmers. The simple descriptive statistics was used to achieve objectives i, ii and iv. While multiple regression analysis using Tobit model was used to achieve objective iii. Multiple regression equation showing the variables used in the research.

\section{RESULTS AND DISCUSSION}

The result in Table 1 revealed that majority $(70 \%)$ of the marketers were within the age bracket of 31 to 50 years with a mean age of 35 years. This implies that most of the marketers are still in their economically active years and physically capable of working and putting more efforts into marketing of perishable crops in order to increase their volume of sale as well as income. This also shows that most traders are strong, able men and women who are capable of performing the marketing activities. However, it implies that the youth involves in marketing of these crops are few in the study areas as most of them are usually assisting either their parents or guardians.

Majority $(69.0 \%)$ of the marketers in the study area were female, while $31.0 \%$ are male. This shows that the female gender is more into marketing of perishable crops which correlates with the work of Asoqwe et al. (2013), who stated that the dominance of the females in the marketing business is as a result of the fact that males have to go to offices, farms and other places in order to ensure the production of these crops as well as provision of the capital (money) required for the family, while the females are engaged in the marketing of these perishable crops.

Findings also show that $44.0 \%$ of the marketers had secondary school education, $22.0 \%$ had primary school education, while $18.0 \%$ had non-formal education and $16.0 \%$ had tertiary education. This suggests that the marketers are averagely educated which gives room for effective communication in carrying out their marketing activities. This is in line with Usman et al. (2008), who stated that educational status of any trader does not only raise his/her profitability, but also it increases his/her ability to understand, evaluate and apply new methods, techniques and processes for better marketing of his goods.

Results further shows that majority $(58.0 \%)$ of the marketers were basically into trading (marketing of perishable produce), while $38.0 \%$ of the marketers were both farmers and traders implying that they are into production of perishable crops and marketing of their produce in the study area. $63.0 \%$ of the marketers who are both farmers and traders have between 0.1 to 2 hectares of farmland, $17 \%$ had between 2 to 4 hectares, $12 \%$ had between 4 to 6 hectares, while only $8 \%$ of them had more than 6 hectares of farm size. The mean farm size was 2.36 hectares implying that the marketers are smallscale farmers producing perishable crops.

Findings also revealed that $40.0 \%$ of the marketers had 6 to 10 years of marketing experience, $24.0 \%$ had less than 5 years and $21.0 \%$ had 11 to 15 years of experience, while $8.0 \%$ had 16 to 20 years of marketing experience. The mean years of marketing experience was 13 years. This implies that most of the marketers have adequate knowledge with regards to marketing perishable crops; fluctuation in prices, in-season and off-season periods. This result is in corroboration with that of Adesina and Kehinde (2008), who expressed that marketing experience enables proper utilization of some resources, decision making as well as planning and timely assessment of alternatives. Majority (69.0\%) of the marketers source of labour is family, $22 \%$ of the marketers use both family and hired labour, while only $9.0 \%$ of the marketers used hired labour in the marketing of perishable products in the study area. This, however, indicates that most of the marketers of these perishable crops in the study area take it as a family business where all individuals participate in one function or the other.

The results further revealed that majority $(73.0 \%)$ of the marketers do not have access to credit facilities, while only $27 \%$ had access to credit. This is in line with Odoemenem and Obinne (2010), who stated that agriculture is a major contributor to Nigeria's GDP and that small-scale farmers/marketers play major roles in the contribution to agricultural production, but their productivity and growth are hindered by lack of and limited access to credit facilities. Furthermore $73.0 \%$ of the marketers does not have any source of credit, $20.0 \%$ had their credit source from commercial institutions, $46.0 \%$ from family and friends, while $3.0 \%$ from cooperative and money lenders. This corroborates with Effiong (2008), who noted that $23 \%$ of the adult population in Nigeria has access to formal 
Table 1. Socio-economic characteristics of the marketers.

\begin{tabular}{|c|c|c|}
\hline Variables & Frequency & Percentage \\
\hline \multicolumn{3}{|l|}{ Age (years) } \\
\hline $21-30$ & 15 & 15.0 \\
\hline $31-40$ & 40 & 40.0 \\
\hline $41-50$ & 30 & 30.0 \\
\hline$>50$ & 15 & 15.0 \\
\hline Total & 100 & 100.0 \\
\hline \multicolumn{3}{|l|}{ Gender } \\
\hline Male & 31 & 31.0 \\
\hline Female & 69 & 69.0 \\
\hline Total & 100 & 100.0 \\
\hline \multicolumn{3}{|c|}{ Marital status } \\
\hline Single & 16 & 16.0 \\
\hline Married & 73 & 73.0 \\
\hline Widowed & 11 & 11.0 \\
\hline Total & 100 & 100.0 \\
\hline \multicolumn{3}{|c|}{ Educational Background } \\
\hline Non-formal & 18 & 18.0 \\
\hline Primary & 22 & 22.0 \\
\hline Secondary & 44 & 44.0 \\
\hline Tertiary & 16 & 16.0 \\
\hline Total & 100 & 100.0 \\
\hline \multicolumn{3}{|l|}{ Occupation } \\
\hline Trader & 58 & 58.0 \\
\hline Farmer & 4 & 4.0 \\
\hline Both & 38 & 38.0 \\
\hline Total & 100 & 100.0 \\
\hline \multicolumn{3}{|c|}{ Household size (No. of Individuals) } \\
\hline $1-5$ & 27 & 27.0 \\
\hline $6-10$ & 49 & 49.0 \\
\hline $11-15$ & 19 & 19.0 \\
\hline $16-20$ & 5 & 5.0 \\
\hline Total & 100 & 100.0 \\
\hline \multicolumn{3}{|c|}{ Farm size (ha) } \\
\hline $0.1-20$ & 63 & 63.0 \\
\hline $2.1-40$ & 17 & 17.0 \\
\hline $4.1-60$ & 12 & 12.0 \\
\hline$>6$ & 8 & 8.0 \\
\hline Total & 100 & 100.0 \\
\hline \multicolumn{3}{|c|}{ Labour usage } \\
\hline Family & 69 & 69.0 \\
\hline Hired & 9 & 9.0 \\
\hline Both & 22 & 22.0 \\
\hline Total & 100 & 100.0 \\
\hline
\end{tabular}

Table 1. Contd.

\begin{tabular}{|c|c|c|}
\hline \multicolumn{3}{|c|}{ Marketing experience(years) } \\
\hline $1-5$ & 24 & 24.0 \\
\hline $6-10$ & 40 & 40.0 \\
\hline $11-16$ & 21 & 21.0 \\
\hline $16-20$ & 8 & 8.0 \\
\hline$>20$ & 7 & 7.0 \\
\hline Total & 100 & 100.0 \\
\hline \multicolumn{3}{|c|}{ Extension Contact } \\
\hline Yes & 71 & 71.0 \\
\hline No & 29 & 29.0 \\
\hline Total & 100 & 100.0 \\
\hline \multicolumn{3}{|c|}{ Access to credit } \\
\hline No & 73 & 73.0 \\
\hline Yes & 27 & 27.0 \\
\hline Total & 100 & 100.0 \\
\hline \multicolumn{3}{|c|}{ Source of credit } \\
\hline None & 73 & 73.0 \\
\hline Agric banks & 20 & 20.0 \\
\hline Cooperatives & 4 & 4.0 \\
\hline Riends/family & 3 & 3.0 \\
\hline Total & 100 & 100.0 \\
\hline \multicolumn{3}{|c|}{ Cooperative membership } \\
\hline No & 30 & 30.0 \\
\hline Yes & 70 & 70.0 \\
\hline Total & 100 & 100.0 \\
\hline
\end{tabular}

Source: Field survey, 2017.

financial institutions, 24\% to informal institutions while 53\% are financially excluded.

Table 2 revealed the result of Tobit regression of the factors influencing marketing of perishable products by the marketers. The t-value revealed that out of the ten (10) independent variables included in the Tobit model, four (4) variables were significant at $1 \%, 5 \%$ and $10 \%$ probability level. Also, the sigma t-value $=14.142$ implying that the overall model is significant at $1 \%$. However, education $\left(X_{3}\right)$, credit $\left(X_{8}\right)$ and cooperative $\left(X_{9}\right)$ had positive coefficients and directly influences marketing of perishable products. This implies that a unit increase in any of the variable will increase marketing of perishable products in the study area. Being quite educated may facilitate the gathering of information on marketing activities by the respondents. This result agrees with the view of Obasi (2008), who observed that better education of the marketers had advantages as it enlightens them on how best to strategize and adapt to better marketing conditions. Also, earlier research reports by Nwaru and Iwuji (2005), showed that education has positive relationship with 
Table 2. Regression coefficients of factors influencing marketing of perishable produce.

\begin{tabular}{lccc}
\hline Variables & Coefficient & Standard error & $\mathbf{t}-$ value \\
\hline Constant & 0.2196 & 0.0891 & $2.465^{\star *}$ \\
Age $\left(X_{1}\right)$ & 0.0029 & 0.0026 & $1.107^{\mathrm{NS}}$ \\
Marital Status $\left(X_{2}\right)$ & 0.0074 & 0.0403 & $0.184^{\mathrm{NS}}$ \\
Education $\left(\mathrm{X}_{3}\right)$ & 0.0079 & 0.0044 & $1.805^{\star}$ \\
Household $\left(\mathrm{X}_{4}\right)$ & -0.0016 & 0.0062 & $-0.263^{\mathrm{NS}}$ \\
Experience $\left(\mathrm{X}_{5}\right)$ & -0.0015 & 0.0042 & $-0.348^{\mathrm{NS}}$ \\
Transportation cost $\left(\mathrm{X}_{6}\right)$ & $-0.6798 \mathrm{D}-05$ & 0.2964 & $-2.294^{\star *}$ \\
Distance $\left(\mathrm{X}_{7}\right)$ & -0.0022 & 0.0031 & $-0.714^{\mathrm{NS}}$ \\
Credit $\left(\mathrm{X}_{8}\right)$ & 0.0956 & 0.0371 & $2.520^{\star * *}$ \\
Cooperative $\left(X_{9}\right)$ & 0.0756 & 0.0379 & $2.038^{\star *}$ \\
Marketing Cost $\left(\mathrm{X}_{10}\right)$ & 0.0049 & 0.0359 & $0.136^{\mathrm{NS}}$ \\
Sigma & -0.1400 & 0.0099 & $14.142^{\star}$ \\
Log likelihood & 54.69597 & & \\
\hline
\end{tabular}

NS = Not Significant, ${ }^{* *}$ Statistically significance at $10 \%$ levels, ${ }^{*}$ Statistically significance at $5 \%$ levels, ${ }^{*}$ Statistically significance at $1 \%$ levels.

Table 3. Distribution of the Marketers based on Losses of Perishable Produce.

\begin{tabular}{lcc}
\hline Losses Recorded & Frequency * & Percentage \\
\hline Harvesting & 15 & 15.0 \\
Transportation & 58 & 58.0 \\
Loading/offloading & 60 & 60.0 \\
Low patronage & 50 & 50.0 \\
\hline
\end{tabular}

Source: Field survey, 2017, * Multiple Response.

marketing margin because of its training advantages which help the marketers to be informed, innovating and averse to marketing risks. Cooperative membership has been identified to be a better way/channel of credit delivery to farmers as well as marketers of agricultural produce than directly from the government and other NGOs (Alufohai, 2006). Credit facilities help to increase the marketing margin as well as efficiency of the marketers.

The analysis further revealed that transportation cost $\left(\mathrm{X}_{6}\right)$ had negative coefficients and inversely influences marketing of perishable products. This implies that a unit increase in the transportation cost of the respondents will definitely decrease marketing of perishable products. The situation of poor road conditions and distance from markets leads to higher transportation costs to crop outputs market, thereby increase transaction costs affecting market participation for perishable produce because the higher the transportation cost, the more difficult and costly it would be to get the produce to the market thereby reducing the quantity taken to the market by the farmers as the results indicated. These results concur with the findings of Mukundi et al. (2013), that increased distance to the market will lower the level of market participation as a result increase marketing costs.

The result in Table 3 revealed that majority $(60.0 \%)$ of the losses in marketing of perishable produce is during loading and off-loading of the crops which could be due to rough handling, $58.0 \%$ of the losses occur during transportation. The resulting long distance from rural areas to urban markets, the bad nature of the roads and spatial nature of markets across cities constitutes reasons why great losses occurs in this stages of marketing of perishable crops. However, $50.0 \%$ of the marketers recorded losses due to low patronage from customers. Since those perishable crops are best consumed in their fresh stage and are susceptible to deterioration either though physical or machinery, or biological causes, the unavailability of customers pose a great treat to customers since storage and processing facilities are not readily available. This result corroborates with that of Kader (2005), who posited that the more a perishable produce stays in the market, exceeding its time of purchase, its deterioration time also increase as possible to minimize mechanical injury such as scratches and bruises to the crop even when storage facilities are available.

Table 4 shows the constraints faced by the marketers of perishable crops in the study area. Majority $(80.0 \%)$ of the marketers indicated poor transportation facilities, $77.0 \%$ of the marketers indicated problem of market location, $74.0 \%$ indicated poor road network linking the farms and the 
Table 4. Constraints Associated with Marketing Perishable Produce.

\begin{tabular}{lcc}
\hline Constraints & Frequency & Percentage \\
\hline Lack of capital & 34 & 34.0 \\
Poor road network & 74 & 74.0 \\
Poor customer attitude & 72 & 72.0 \\
Perishable nature of the produce & 59 & 59.0 \\
Problem of market location & 77 & 77.0 \\
Poor transportation facilities & 80 & 80.0 \\
Inadequate processing facilities & 37 & 37.0 \\
Price fluctuation & 43 & 43.0 \\
Climatic condition & 14 & 14.0 \\
\hline
\end{tabular}

Source: Field survey, 2017, *Multiple Response.

markets. This finding is in agreement with the work of Izekor and Abiola (2011), which revealed that poor transportation and road network are major constraints to post harvest losses in perishable crop marketing. Furthermore, $72.0 \%$ of the marketers indicated poor customer attitudes, $59.0 \%$ indicated perishable nature of the produce and $37.0 \%$ indicated inadequate processing facilities. This corroborates with the results of Oladejo and Oladiran (2014), in their work of the analysis of consumption pattern and marketing of perishable crop, stating that major challenge is rapid deterioration in tomatoes, pepper and vegetable is due to their perishable nature.

\section{Conclusion and recommendation}

The study examined the factors affecting the marketing of perishable agricultural crops in Minna. The combination of analytical techniques was used in the study. Descriptive statistics (percentage and means) were used to determine the major constraints while multiple regression analysis using tobit-models were used to achieve the objectives of the study. The study revealed that $70.0 \%$ of the marketers were within the age of 31 to 50 years showing that majority of the marketers are still active. Perishable agricultural crops marketing was dominated by the female gender $(69.0 \%)$. Findings also revealed that about $61.0 \%$ of the marketers had marketing experience of between 6 to 15 years implying that majority of the marketers have adequate knowledge about perishable crops marketing, $69.0 \%$ of the marketers use family members as their source of labour, $71.0 \%$ of the marketers had no contact with extension agents, implying that information with regards to new innovations hardly reach them. The research further shows that $73.0 \%$ of the marketers do not have any source or access to credits facility within the study area, however $70.0 \%$ of the marketers were members of cooperatives or association. Tobit regression was used to determine the factors influencing marketing of perishable agricultural products, it was discovered that the t-value shows that out of the ten (10) independent variables, four (4) variables were significant. Education $\left(X_{3}\right)$, credit $\left(X_{8}\right)$ and cooperative $\left(X_{9}\right)$ had positive coefficient and directly influences marketing of perishable produce in the study area. Also transportation cost $\left(\mathrm{X}_{6}\right)$ had negative coefficient and inversely influences marketing of perishable products. Findings also revealed that deterioration of quality, price fluctuation, availability of the produce and distance were major challenges faced by the marketers. The study therefore examines some of the constraints faced by the marketers of perishable crops that leads to losses; the socio economic characteristics, mode and cost of transportation, years of marketing experiences, distance as well as other control variables were also included. Based on the research findings, the following recommendations were made;

1. Farm household should be encouraged and empowered through NGO's to access educational institutions around them in order to develop their skills.

2. Policies that guide the federal, state and local governments towards increased investment in rural infrastructure should be strictly implemented. This will help reduce transaction costs and thereby improve participation of small holder farmers in marketing activities.

3. The Ministry of Agriculture through Agricultural Development Programme (ADP) should sensitize the small holder farmers on the need to form cluster cooperatives as this will help in accessing credits from the government and other financial institutions.

4. Market opportunities should be fully developed through provision of adequate infrastructure; such development will boost domestic market transaction in perishable produce.

Better storage and processing facilities should be established through the NGO's and cooperative associations so as to simplify the processing of these perishable crops.

5. The small holder farmers in the study area should ensure timely harvest of these perishable crops. 


\section{REFERENCE}

Adesina, C. A., \& Kehinde, A. L. (2008). Economics of Wholesales Marketing of Tomato Fruits in Ibadan Metropolis of Oyo State, Nigeria. Journal of Agriculture, Forestry and the Social Sciences, 6(1).

Alufohai, G. O. (2006). Sustainability of Farm Credit delivery by Cooperatives and NGOs in Edo and Delta states, Nigeria. Educational Research and Review, 1(8), 262-266.

Antwi. M., \& Seahlodi, P. (2011). Marketing Constraints Facing Emerging Small-Scale Pig Farmers in Gauteng Province, South Africa. Journal of Human Ecology, 36(1), 37-42.

Asoqwe, B. C., Ezihe J. A.C., \& Alev, P. (2013). Socio analysis of cassava marketing in River State, Nigeria. International Journal of Innovation and Applied Studies, 2(4), 384-391.

Balarane, A., \& Oladele, O. I. (2012). Awareness and use of agricultural market information among small scale farmers in Ngaka Modiri Molema District of North West Province. Life Science Journal, 9(3), 57-62.

Baloyi, J. K. (2010). An analysis of constraints facing smallholder farmers in the Agribusiness value chain: A case study of farmers in the Limpopo Province. Unpublished dissertation. Available https://repository.up.ac.za/bitstream/handle/2263/29038/disse rtation.pdf?sequence=1. Retrieved 25th March, 2013.

Barham, J., \& Chitemi, C. (2009). Collective action initiatives to improve marketing performance: Lessons from farmer groups in Tanzania. Food Policy, 34, 53-59.

Bothloko, G. J., \& Oladele, O. I. (2013). Factors Affecting Farmers Participation in Agricultural projects in Ngaka Modiri Molema District North West Province, South Africa. Journal of Human Ecology, 41(3), 201-206.

Effiong, E. O. (2008). Efficiency of production in selected livestock Enterprises in Akwa-lbom State, Nigeria. Unpublished PhD. Thesis, Department of Agricultural Economics, Michael Okpara University of Agriculture, Umudike.

Gustavsson, J., Cederberg, C., Sonesson, U., van Otterdijk, R., Meybeck, A. (2011). Global Food Losses and Food Waste: Extent Causes and Prevention. Food and Agriculture Organization (FAO) of the United Nations, Rome.

Ikujebi, O. A. (2017). Analysis of the competitiveness of tomato production in Kokona Local Government Area of Nasarawa State, Nigeria. Unpublished Bachelor of Agriculture project submitted to the Department of Agricultural Economics and Extension, Faculty of Agriculture, Nasarawa State University, Keffi, Nigeria.

Izekor, O. B., \& M. O Abiola. (2011). Analysis of Post-Harvest Losses in Green Vegetable (Amaranthus cruentus) during Marketing in Benin Metropolis, Edo State, Nigeria. International Journal of Agricultural Economics and Extension Services, 1(1), 129-135.

Kader, A. A. (2004). Increasing food availability by reducing postharvest losses of fresh produce. Proceedings of the 5th International Postharvest Symposium 682. Pp. 2169-2176.

Mukundi, E., Mathenge, M. K., \& Ngigi, M. (2013). Sweet potato marketing among smallholder farmers: the role of collective action. In 2013 AAAE Fourth International Conference, September 22-25, 2013, Hammamet, Tunisia (No. 160679). African Association of Agricultural Economists (AAAE).

Niger Geographical Information System (NIGIS) (2014).
Nwaneri, T. C., Ume, S. I., Chukwu, O. A., Ben-chukwu, M. A., Orji, P. N., \& Aroh, J. E. (2016). Economics of Okra Marketing in Ivo Local Government Area, Ebonyi State, Nigeria. Proceedings of the $50^{\text {th }}$ Annual Conference of the Agricultural Society of Nigeria\{ASN), P. 24.

Nwaru, J. C., \& Iwuji, O. (2005). Marketing Margins and their Determinants in Plantain Marketing in Owerri Agricultural Zone of Imo State, Nigeria; Agricultural Rebirth for Improved Production in Nigeria; In: Orherliata.

Obasi, I. O. (2008). Structure, Conduct and Performance of Rice Marketing in Abia State, Nigeria. Unpublished Master Thesis. Michael Okpara Univeristy of Agriculture, Umudike, Nigeria

Odoemenem, I. U., \& Obinne, C. P. O. (2010). Assessing the Factors Influencing the Utilization of Improved Cereal Crop Production Technologies by Small Scale Farmers In Nigeria. Indian Journal of Science and Technology, 3(1), 180-183.

Oladejo, J. A., \& Oladiran, J. O. (2014). Marketing Analysis and Consumption Pattern of Tomato in Oyo State, Nigeria. International Journal of Agriculture Innovations and Research, 2(5), 2319-1473.

Olayemi, F. F., Adegbola, J. A., Bamishaiye E. I., \& Aawagu, E. F. (2012). Assessment of postharvest losses of some selected crops in eight local government areas of rivers state, Nigeria. Asian journal of rural development, 2(1), 13-23.

Onyenobi, V. O., Ezehand, C. I., \& Emerole C. O. (2015). Ordered Proit Analysis of Factors Influencing Market Participation Decisions by Male and Female Retailer Heads of Households in Minituber Yam Marketing in Abia State, Nigeria. Proceedings of the Forty-Ninth Annual Conference of the Agricultural Society of Nigeria(ASN), Delta, 2015. P. 69.

Salami, A., Kamara, A. B., \& Brixiova, Z. (2010). Smallholder agriculture in East Africa: Trends, constraints and opportunities. African development group, working paper series No 105, African Development Bank, Tunis, Tunisia.

Samantaray, S. K, Prusty, S., \& Raj, R. K. (2009). Constraints in Vegetable Production-Experiences of Tribal Vegetable Growers. Indian Research Journal of Extension Education, 9(3), 32-34.

Tita, D. F. (2009). A transaction cost analysis of factors affecting market arrangements in the agroforestry tree product value chain in Cameroon. International Master of Science in Rural Development, p. 131.

Umeh, S. I., Okoronkwo, M. O., Ahaiwe, M. O., Ogwulumba, S. I., \& Umeh, S. I. (2016). Marketing of Fluteg Pumpkin Among Wholesalers and Retailers in Essan West Local Government Area of Edo State, Nigeria. Proceedings of the 50th Annual Conference of the Agricultural Society of Nigeria\{ASN), p. 218.

Usman, M. B., Omoayena, B. O., \& Ishaya, B. E. (2008). Marketing Analysis of cabbage in Jos South Local Government Area of Plateau State. Proceedings of the 20th Annual National Conference of Farm Management Association of Nigeria (FAMAN).

Xaba, B. G., \& Masuku, M. B. (2012). Factors affecting the choice of marketing channel by vegetable farmers in Swaziland. Sustainable Agriculture Research, 2(1), 112. 